\title{
Reactive oxygen species as important regulators of cell division
}

Weiliang Qi $i^{1,2,3,4}$ Li Ma ${ }^{1,2,3}$, Fei Wang ${ }^{4}$, Ping Wang ${ }^{4}$, Junyan Wu ${ }^{1,2,3}$, Jiaojiao Jin ${ }^{1,2,3}$, Songqing

Liu $^{4}$, Wancang Sun*1,2,3

${ }^{1}$ College of Agronomy, Gansu Agricultural University, Lanzhou, China.

${ }^{2}$ Gansu Provincial Key Laboratory of Arid land Crop Science, Gansu Agricultural University, Lanzhou, China.

${ }^{3}$ Key Laboratory of Crop Genetics Improvement and Germplasm Enhancement of Gansu Province, Lanzhou, China.

${ }^{4}$ College of Chemistry and Life Science, Chengdu Normal University, Chengdu, China.

Current address: Gansu Agricultural University, Anning District of Lanzhou, China

Corresponding Author: Dr. Wancang Sun

E-mail:18293121851@163.com

Abstract: Currently, the role of reactive oxygen species (ROS) in plant growth is a topic of interest. In this study, we discuss the role of ROS in cell division. We analyzed ROS' impact on the stiffness of plant cell walls and whether ROS play an important role in Brassica napus' ability to adapt to cold stress. Cultivated sterile seedlings and calli of cold-tolerant cultivar 16NTS309 were subjected to cold stress at $25^{\circ} \mathrm{C}$ and $4^{\circ} \mathrm{C}$, respectively. Under normal conditions, $\mathrm{O}^{2--}$ mainly accumulated in the leaf edges, shoot apical meristem, leaf primordia, root tips, lateral root primordia, calli of meristematic nodular tissues, cambia, vascular bundles and root primordia, which are characterized by high division rates. After exposure to cold stress, the malondialdehyde and $\operatorname{ROS}\left(\mathrm{O}^{2--}\right)$ contents in roots, stems and leaves of cultivar 16NTS309 were significantly higher 
than under non-cold conditions $(P<0.05)$. ROS $\left(\mathrm{O}^{2--}\right)$ were not only distributed in these zones, but also in other cells, at higher levels than under normal conditions. A strong ROS-based staining appeared in the cell wall. The results support a dual role for apoplastic ROS, in which they have direct effects on the stiffness of the cell wall, because ROS cleave cell-wall, and act as wall loosening agents, thereby either promoting or restricting cellular division. This promotes the appearance of new shoots and a strong root system, allowing plants to adapt to cold stress.

Key words: ROS, cell division, sterile seedlings, callus, Brassica napus

All living organisms, including plants, face extremes of sudden and adverse environmental conditions, such as cold, but unlike animals, plants are sessile and, therefore, cannot move to avoid stress $[1,2]$. Cold stress is an abiotic stress that severely negatively impacts the growth and development of plants during any developmental stage, germination, seedling, vegetative, reproductive or grain maturity, leading to a reduction in grain yield. However, cold stress is one of a multiplex of factors in a specific environment that affects plants [3] and results in different types of reactive oxygen species (ROS) production in plants, including singlet oxygen, superoxide anion $\left(\mathrm{O}^{2 .-}\right)$, hydrogen peroxide $\left(\mathrm{H}_{2} \mathrm{O}_{2}\right)$ and hydroxyl radicals [4-7]. Currently, the role of reactive oxygen species (ROS) in plant growth is a topic of interest. ROS not only act as signals in cells that activate a number of different defense mechanisms to protect cells[8], but also damage cells. ROS signaling mechanisms also play important roles in regulating the balance between cell proliferation and differentiation in both animals and plants [9]. In Drosophila, changing ROS levels can switch the status of hematopoietic cells from proliferation to differentiation[10]. ROS have direct effects on the stiffness of the plant cell wall, either promoting or restricting cellular 
division $[11,12]$. Thus, it is necessary to determine and understand any correlation between ROS and cell division.

Winter rapeseed (Brassica napus), as a cover crop, helps to eliminate a dust source for the damaging sand storms in northern China. It is not only possible, but also beneficial economically, environmentally and ecologically, to grow winter rapeseed in dry and cold regions in northwestern China $[13,14]$. However, the low temperatures in the winter make it difficult for B. napus varieties to survive $[7,13]$. To improve the plant's resistance to cold stress, the antioxidant capacity needs to be increased as does our understanding of the role of ROS in plant growth. Tissue culture-based approaches are convenient to operate under controlled environmental conditions, requiring less time and space (Fig 1). They are used to investigate the physiology and biochemistry of plants cultured under various environmental stress conditions [15]. To ensure the veracity of the experiment data, sterile seedlings need to be cultivated, unlike in field trials [16]. The advantage of this method is that ROS production, in response to biotic or abiotic stresses that occur when materials are treated in the natural environment, can be excluded .

Our research group studied the feasibility of expanding winter rapeseed northwards into cold regions in northwestern China and bred new lines of B. napus having a strong cold tolerance, which could over winter in the $36^{\circ} 03^{\prime} \mathrm{N}$ area at an altitude of $2,150 \mathrm{~m}$. These are the essential $B$. napus germplasm resources having strong cold tolerance levels used for breeding in northern China [17]. Physiological responses to low temperatures in B. napus have been intensively investigated, but the ROS signaling mechanisms underlying cold tolerance and resistance in plants is still rather poorly understood. In this study, we address several key questions: What is the correlation between ROS and cell division? Do ROS signaling mechanisms play important roles in 
the stiffness of the plant cell walls, thereby promoting root and leaf growth and differentiation?

Does this promote new shoots and strong root systems that are required to adapt to cold stress?

The aim was to provide new insights on the physiological and biochemical mechanisms and cytology associated with responses of B. napus to cold stress for use in breeding cold-resistant varieties.

\section{Materials and methods}

\subsection{Cultivating sterile seedlings and calli of 16NTS309.}

The B. napus cultivar 16NTS309 (strongly resistant to cold damage) was produced by the Key Laboratory of Crop Genetics Improvement and Germplasm Enhancement of Gansu Province, Lanzhou. Plant sterile seedlings and calli of B. napus cultivar 16NTS309 were established using seeds and leaves. Initially, to produce sterile seedlings, seeds were soaked for $8 \mathrm{~h}$ and surface-sterilized with $75 \%$ alcohol for $30 \mathrm{~s}$, followed by $0.5 \% \mathrm{HClO}$ for $8 \mathrm{~min}$. Then, the seeds were placed in 200-mL flasks containing $50 \mathrm{~mL}$ of liquid MS medium. The medium containing MS salts was supplemented with $15 \mathrm{~g} \cdot \mathrm{L}^{-1}$ saccharose and $17.5 \mathrm{~g} \cdot \mathrm{L}^{-1}$ agar, adjusted to $\mathrm{pH} 6.0$ with $\mathrm{NaOH}$ or $\mathrm{HCl}$ and autoclaved at $121^{\circ} \mathrm{C}$ for $20 \mathrm{~min}$. The growth conditions were 18 -h light: 6-h dark photocycles at $22^{\circ} \mathrm{C}$. In total, 100 sterile seedlings were obtained after $5 \mathrm{~d}$ of incubation. Then, calli were induced from leaves of sterile seedlings that were placed on callus-generating medium containing MS salts supplemented with $1 \mathrm{mg} \cdot \mathrm{L}^{-1}$ 2,4-dichlorophenoxyacetic acid (2,4-D )and $1 \mathrm{mg} \cdot \mathrm{L}^{-1} 6$-benzylaminopurine (6-BA) that had been adjusted to $\mathrm{pH} 6.0$ with $\mathrm{NaOH}$ or $\mathrm{HCl}$ and then autoclaved at $121^{\circ} \mathrm{C}$ for $20 \mathrm{~min}$. In total, 90 calli were obtained after $7-14 \mathrm{~d}$ of incubation. Finally, sterile seedlings and calli of B. napus cultivar16NTS309 were divided into 
bioRxiv preprint doi: https://doi.org/10.1101/2020.03 06.980474 this version posted March 6, 2020. The copyright holder for this preprint (which was not certified by peer review) is the author/funder, who has granted bioRxiv a license to display the preprint in perpetuity. It is made available under aCC-BY 4.0 International license.

two groups: one was maintained at $25^{\circ} \mathrm{C}$ as the non-cold control and the other was subjected to cold stress at $4^{\circ} \mathrm{C}$. To determine whether ROS were produced in the extracellular and intracellular environment, we conducted the same experiments using onions and subjected them to histochemical staining.

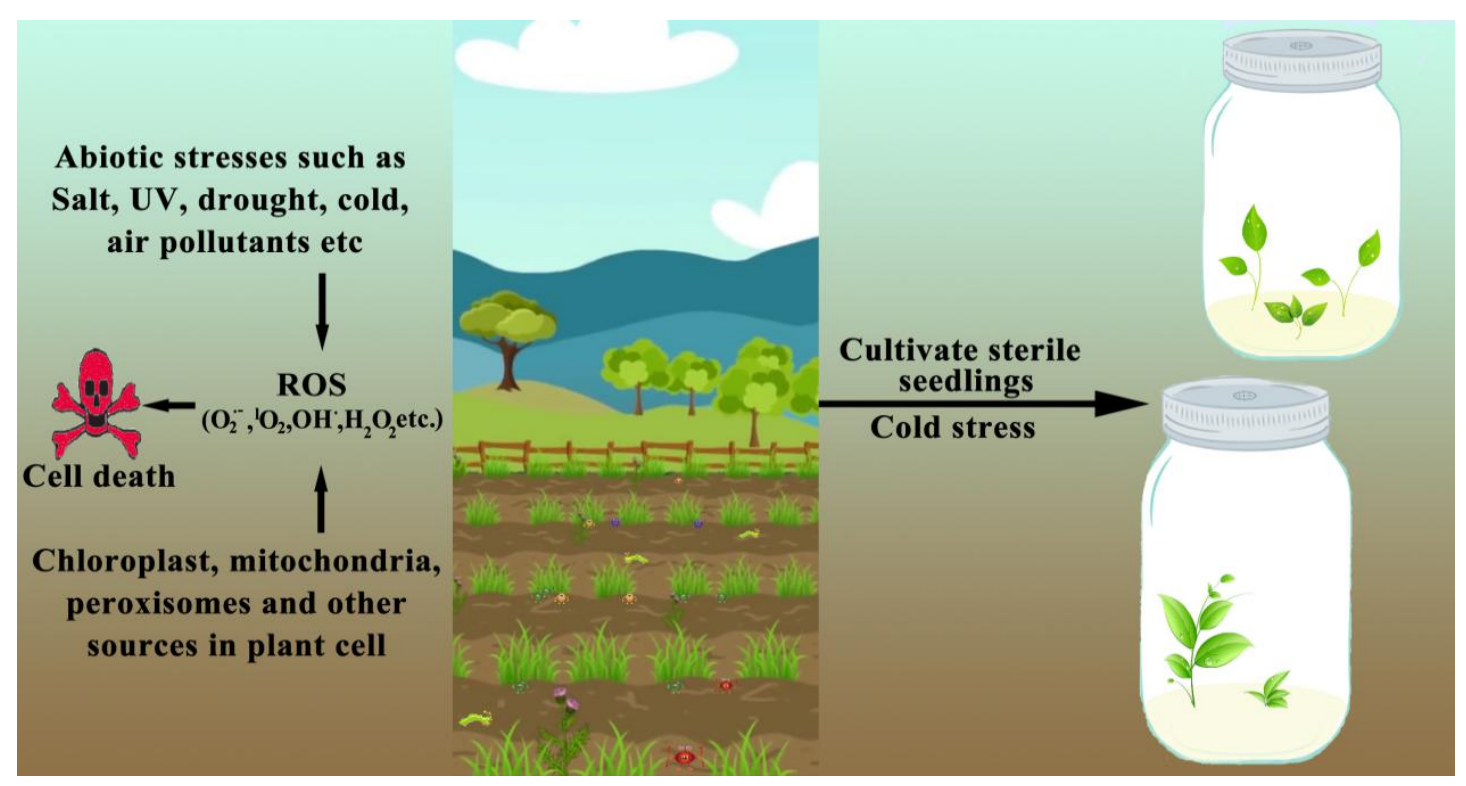

Fig 1 Cultivating sterile seedlings and calli of B. napus cultivar 16NTS309. Abiotic and biotic stresses are factors in a specific environment that can severely negatively affect plant growth, resulting in the production of different types of ROS. Tissue culture approaches have proven to be more convenient under controlled environmental conditions, requiring limited time and space. The advantage of this method is that it can exclude ROS production in response to biotic stresses that occur when materials are treated in a natural environment.

\subsection{Physiological index method}

Indexes of the malondialdehyde (MDA) and $\operatorname{ROS}\left(\mathrm{O}^{2--}\right)$ contents were analyzed as indicators of physiological responses[18, 19]. Root, stem and leaf samples from cultivated sterile 16NTS309 
104

seedlings were taken for morphological and physiological these analyses. The indexes were statistically analyzed using SPSS 19.0.

\subsection{Detection of $\operatorname{ROS}\left(\mathrm{O}^{2 \cdot-}\right)$}

To determine the distribution of $\operatorname{ROS}\left(\mathrm{O}^{2--}\right)$, in the plants, we stained plants with nitroblue tetrazolium (NBT), which is widely used as an indicator of $\operatorname{ROS}\left(\mathrm{O}^{2--}\right)$ levels. The detection of $\operatorname{ROS}\left(\mathrm{O}^{2--}\right)$ was assessed as previously described [20]. Briefly, plants were immersed for $8 \mathrm{~h}$ in 1 $\mathrm{mg} \cdot \mathrm{mL}^{-1}$ NBT staining solution, which was protected from light. After infiltration, the stained plants were bleached in an acetic acid:glycerol:ethanol $(1: 1: 3, \mathrm{v} / \mathrm{v} / \mathrm{v})$ solution at $100^{\circ} \mathrm{C}$ for $10-20$ min and then stored in $95 \%(\mathrm{v} / \mathrm{v})$ ethanol until scanned.

\subsection{Tissue section}

NBT specifically reacts with $\mathrm{O}^{2--}$ and forms a blue formazan precipitate. The $16 \mathrm{NTS} 309$ root, leaf and callus samples having the deepest blue formazan precipitate were sectioned for the morphoanatomical analysis. These samples were fixed in $50 \%$ mixed liquor of formalin-aceticacid-alcohol (FAA), softened using 20\% ethylenediamine and embedded in paraffin. The samples were sectioned using a rotary microtome and stained with PAS, naphthol yellow or saffron, solid green staining. Slides were mounted in synthetic resin and images were captured using a digital image acquisition system.

\section{Results}

\subsection{The physiological indexes of MDA and $\operatorname{ROS}\left(\mathrm{O}^{2 \cdot-}\right)$}

Under cold-stress conditions, the physiological indexes of MDA and ROS $\left(\mathrm{O}^{2--}\right)$ in roots, stems and leaves of cultivar 16NTS309 were measured. After $48 \mathrm{~h}$ of cold stress, the MDA and ROS 
$\left(\mathrm{O}^{2--}\right)$ contents were significantly higher in roots, stems and leaves compared with under non-cold conditions $(P<0.05)$. Under cold-stress conditions, the ROS contents in 16NTS309 roots, stems and leaves reached $216.397 \mu \mathrm{g} \cdot \mathrm{g}^{-1}$ fresh weight $(\mathrm{FW}), 163.267 \mu \mathrm{g} \cdot \mathrm{g}^{-1} \mathrm{FW}$ and $217.627 \mu \mathrm{g} \cdot \mathrm{g}^{-1} \mathrm{FW}$, respectively (Fig 2A). The MDA contents in roots and leaves of 16NTS309 reached 0.61 $\mu \mathrm{mol} \cdot \mathrm{g}^{-1}$ and $0.55 \mu \mathrm{mol} \cdot \mathrm{g}^{-1}$, respectively, which were higher than the level in stems (Fig $2 \mathrm{~B}$ ).
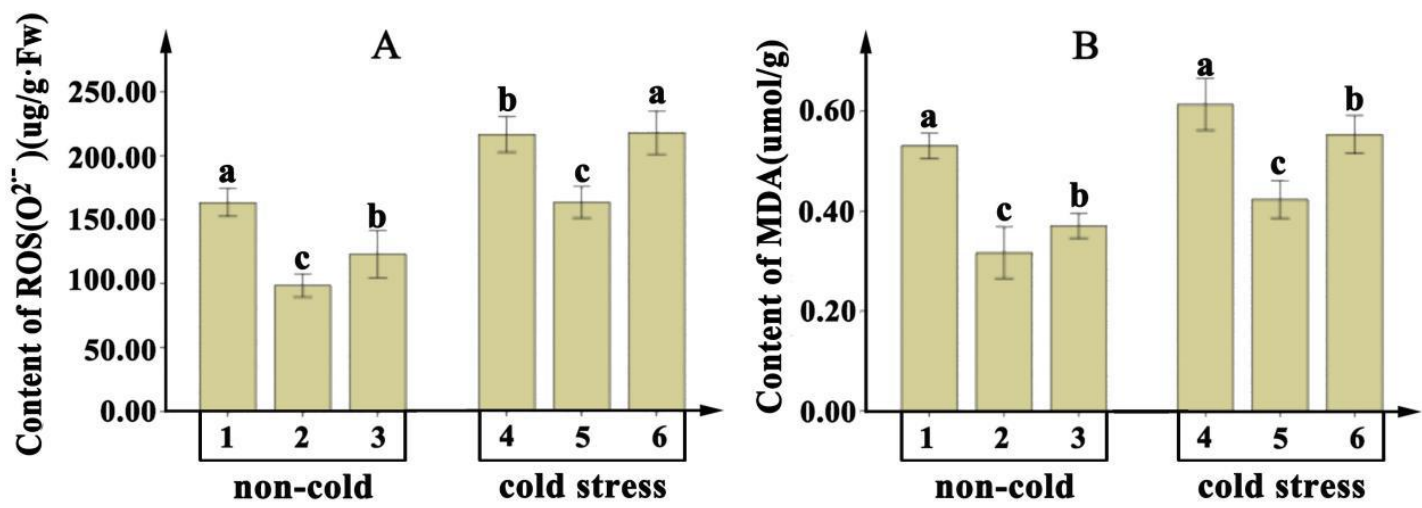

Fig 2 The physiological indexes of MDA and $\operatorname{ROS}\left(\mathrm{O}^{2--}\right)$ were analyzed in root (1 and 4), stem (2 and 5) and leaf (3 and 6) samples from cultivated sterile Brassica napus 16NTS309 seedlings exposed to non-cold and cold-stress conditions.

\subsection{Detection of $\operatorname{ROS}\left(\mathrm{O}^{2 \cdot-}\right)$ in leaves and roots}

The shoot apical meristem (SAM) is the distal-most portion of the shoot and comprises two groups of cells: the initial or source cells and the progenitor cells of tissues and lateral organs [21, 22] By contrast, the shoot apex comprises several cell and tissue types: the SAM itself, a region just proximal to the meristem, in which lateral organ primordia, such as leaf primordia (LPs), form, a sub-apical region, in which the shoot widens and primordia enlarge, and the region of maturation, in which differentiation becomes apparent $[21,22]$. We found a similar phenomenon in B. napus cultivar 16NTS309. Under normal conditions, the main ROS $\left(\mathrm{O}^{2--}\right)$ concentrations were in leaf 
bioRxiv preprint doi: https:/doi.org/10.1101/2020.03.06.980474 this version posted March 6,2020 . The copyright holder for this preprint (which was not certified by peer review) is the author/funder, who has granted bioRxiv a license to display the preprint in perpetuity. It is made available under aCC-BY 4.0 International license.

143

edges (Fig 3a, e, f), SAM and LPs (Fig 3c, d). This organization was the same as cells having a strong division capacity. Presumably there is a correlation between $\mathrm{ROS}\left(\mathrm{O}^{2--}\right)$ and cell division.

After exposure to cold stress, the ROS $\left(\mathrm{O}^{2--}\right)$ level increased in leaves (Fig $\left.3 g, k, 1\right)$, LPs and SAM

(Fig $3 \mathrm{i}$, j) to greater levels than under normal conditions.
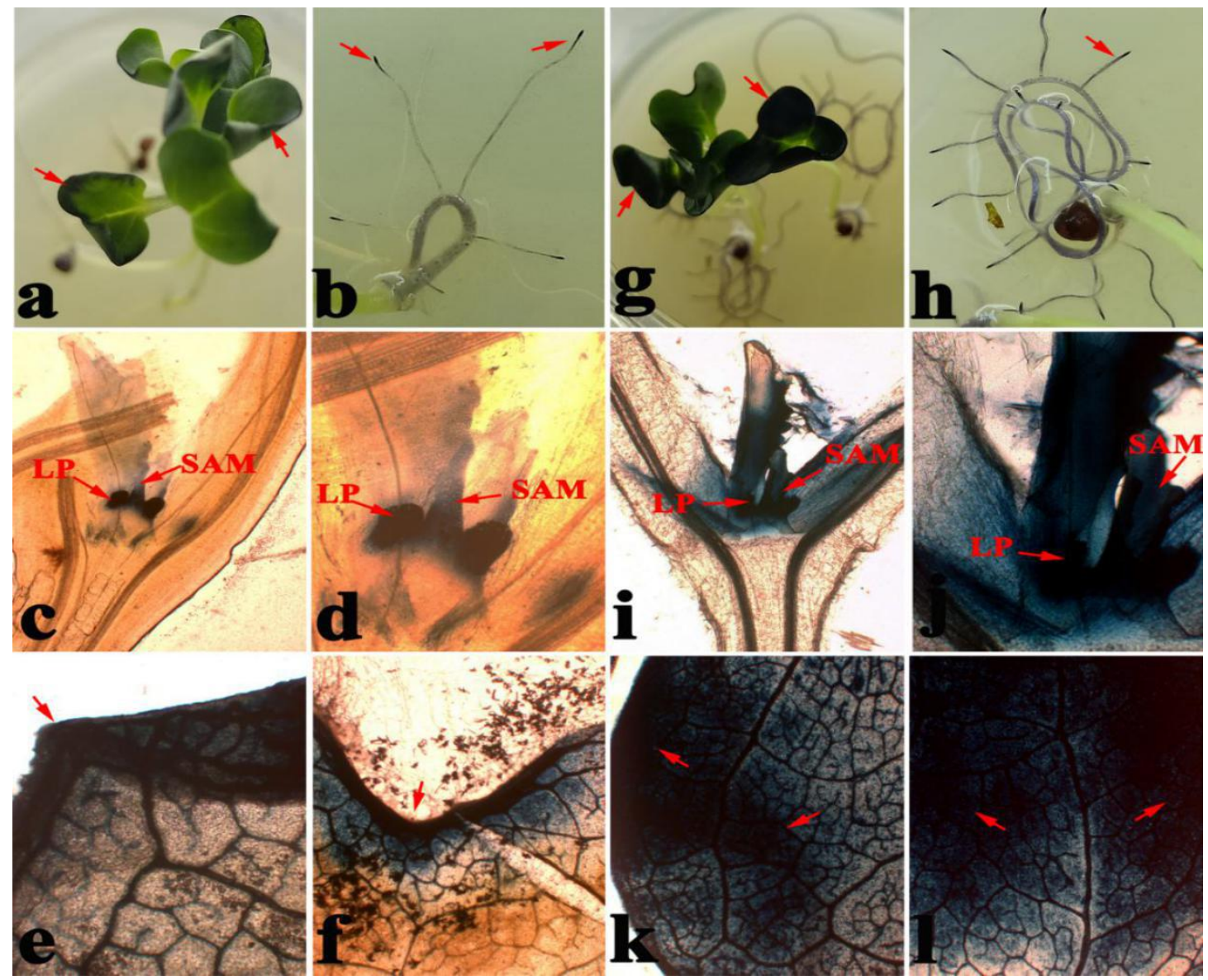

Fig 3 To determine the distribution of $\mathrm{O}^{2--}$ in the leaves, plant tissues were stained with nitroblue tetrazolium (NBT), which is widely used as an indicator of $\mathrm{O}^{2--}$ levels. The $\mathrm{O}^{2 .-}$ levels in NBT-stained cultivar 16NTS309 seedlings under non-cold (a, b, c, d, e, f) and cold-stress (g, h, i, j, k, l) conditions. SAM: Shoot apical meristems; LP: leaf primordial. Red arrows were indicated super oxide anion $\left(\mathrm{O}^{2 \cdot-}\right)$ by dispersion polymerization product of blue spots. 
bioRxiv preprint doi: https://doi.org/10.1101/2020.03 06.980474 this version posted March 6, 2020. The copyright holder for this preprint (which was not certified by peer review) is the author/funder, who has granted bioRxiv a license to display the preprint in perpetuity. It is made available under aCC-BY 4.0 International license.
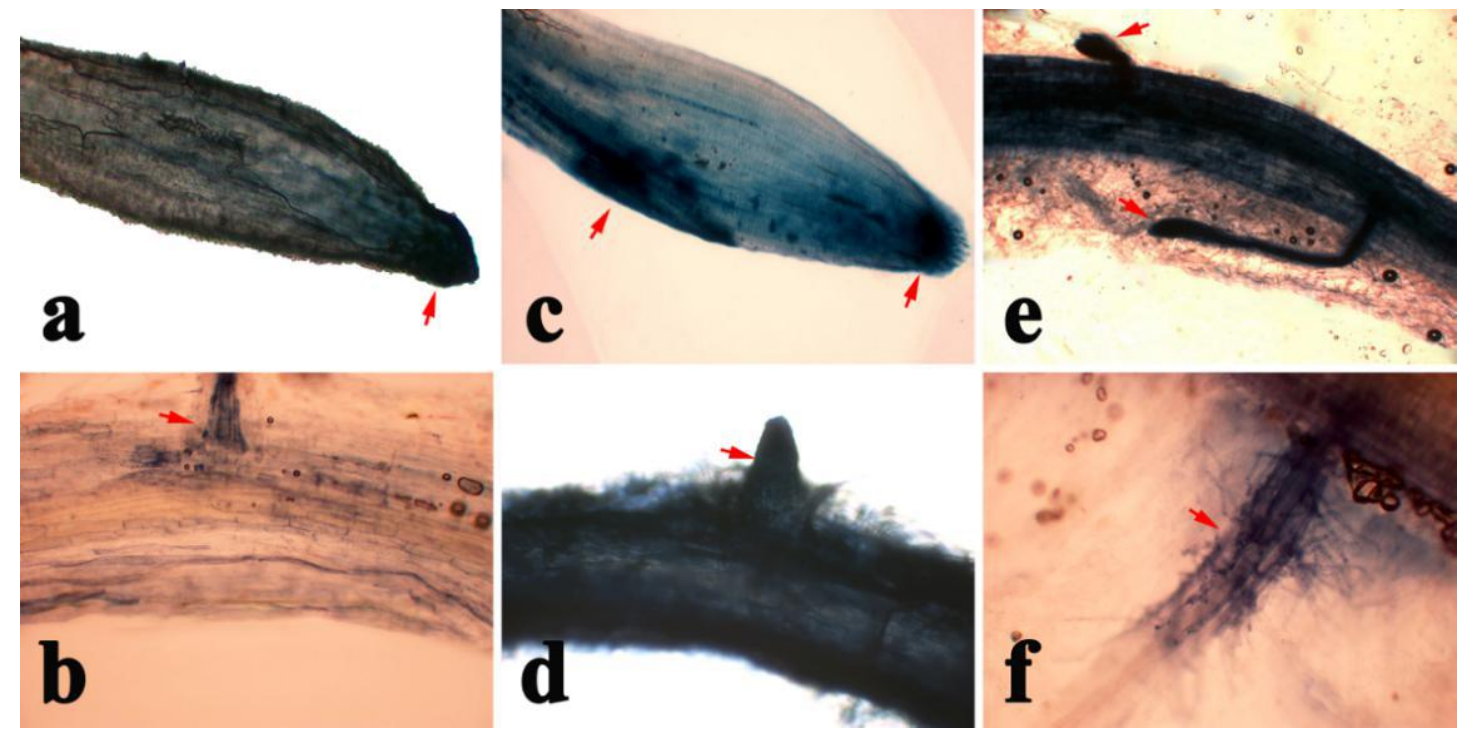

Fig 4 To determine the distribution of $\mathrm{O}^{2--}$ in Brassica napus root, we stained plants with nitroblue tetrazolium (NBT), which is widely used as an indicator of $\mathrm{O}^{2--}$ levels. The $\mathrm{O}^{2 .-}$ levels in NBT-stained cultivar 16NTS309 seedlings under non-cold (a and b) and cold stress (c, d, e f) conditions. lateral root primordium(LRP). Red arrows were indicated super oxide anion $\left(\mathrm{O}^{2 \cdot-}\right)$ by 


\subsection{Histological observations of $\operatorname{ROS}\left(\mathrm{O}^{2 \cdot-}\right)$ in root and leaf cells}

The NBT-stained blue sections of roots and leaves from aseptic seedling used for the morphoanatomical analysis were selected for histological observation. Varying degrees of ROS $\left(\mathrm{O}^{2--}\right)$ accumulation occurred in root and leaf cells under both normal and cold-stress conditions.

Under normal conditions, $\mathrm{ROS}\left(\mathrm{O}^{2--}\right)$ were mainly distributed in meristematic cells along leaf edges (Fig 5a) and cambium cells of roots (Fig 6a). The histology of these cells was similar to cells having a strong capacity to proliferate. ROS signals were not detected in other cells.

After exposure to a cold stress of $4^{\circ} \mathrm{C}$, ROS accumulations in cells of roots (Fig 6b), leaves (Fig 5b) were obviously greater than under normal conditions. Leaves are composed of an epidermis, mesophyll and veins. The mesophilic cells near the upper epidermis are cylindrical, forming the palisade tissue, which contains more chloroplasts. The mesophyll cells near the lower epidermis are irregular in shape and loose in arrangement. A greater ROS content accumulated in palisade cells compared with that in other leaf cells, possibly because the latter form spongy tissues containing few chloroplasts.

The root structure, including the epidermis, secondary phloem, secondary xylem, cambium and vascular cylinder, has wide parenchymatous rays. Cambium, which is located between the phloem and xylem in roots, had a large ROS content. LRP initiation is the appearance of closely spaced cell walls in the cambial layer in a perpendicular orientation to the root axis (Fig 6b). The increased cell division frequency and ROS accumulation were clearly seen when compared with cambial cells from the opposite side of the stele. These phenomena confirmed that ROS plays an important role in regulating the balance between cell proliferation and differentiation, by promoting root, stem and leaf growth. 
bioRxiv preprint doi: https://doi org/10.1101/2020 03 66 980474. this version posted March 6, 2020. The copyright holder for this preprint (which was not certified by peer review) is the author/funder, who has granted bioRxiv a license to display the preprint in perpetuity. It is made available under aCC-BY 4.0 International license.
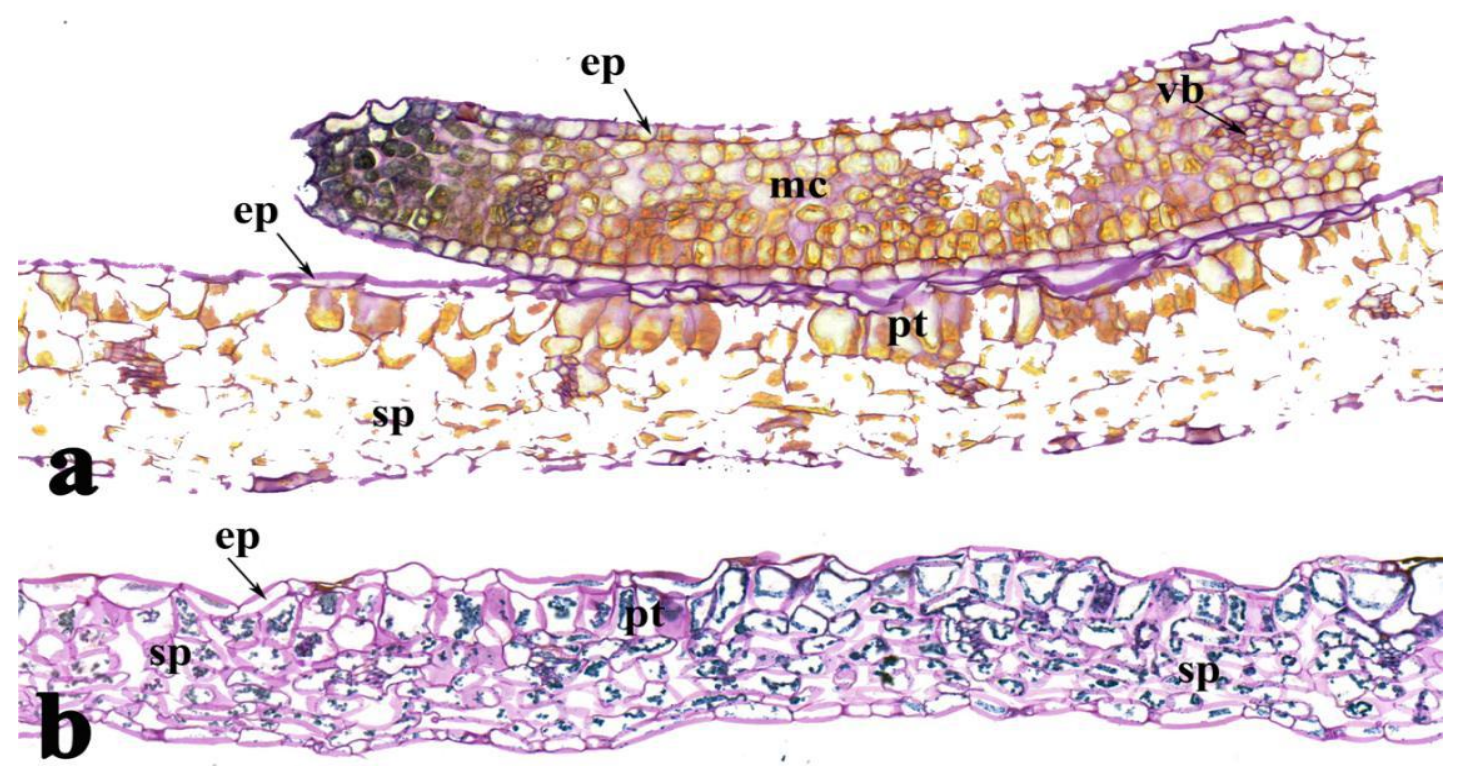

192

193

Fig 5 Brassica napus cultivar 16NTS309 subjected to non-cold (a) and cold-stress (b) conditions

for $48 \mathrm{~h}$. The regions of 16NTS309 leaves samples containing the most blue formazan precipitate were sectioned for morphoanatomical analyses. ep, epidermis; sp, secondary phloem; mc, mesophyll cell; pt, palisade tissue; vb, vascular bundle.
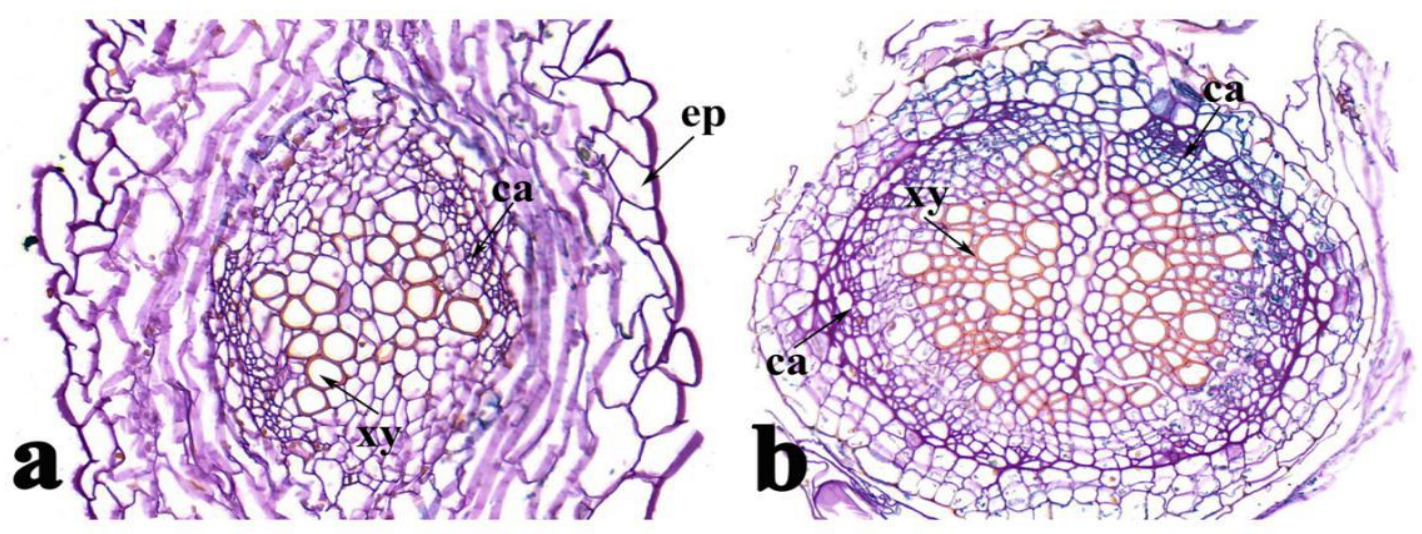

Fig 6 Brassica napus cultivar 16NTS309 subjected to non-cold (a) and cold-stress (b) conditions for $48 \mathrm{~h}$. The regions of 16NTS309 roots samples containing the most blue formazan precipitate were sectioned for morphoanatomical analyses. ep, epidermis; ca, cambium; xy, xylem.

\subsection{Histological observation of $\operatorname{ROS}\left(\mathrm{O}^{2 \cdot-}\right)$ in tissues}

All plant cells have been traditionally thought of as being totipotent because plant tissues can be 
bioRxiv preprint doi: https://doi.org/10.1101/2020 03 06 980474 this version posted March 6,2020 . The copyright holder for this preprint (which was not certified by peer review) is the author/funder, who has granted bioRxiv a license to display the preprint in perpetuity. It is made available under aCC-BY 4.0 International license.

203

204

induced to form shoots and roots[26-28]. Consequently, we selected the NBT-stained blue sections of calli for histological observation. In vitro, plant tissues having a greater cell-division capacity had greater ROS accumulations under normal conditions, including meristematic nodular tissues, cambium, vascular bundles and root primordium (Fig 7a), while there was little or no ROS accumulation in other cells (Fig 7b). After exposure to cold stress, the ROS distributed in meristematic nodular tissues, cambium, vascular bundles (Fig 7c, d), and other cells increased greatly (Fig 7e). This phenomenon indicated that ROS plays an important role in regulating the balance between cell proliferation and differentiation. ROS signals were detected mainly in cell walls, possibly because ROS have essential functions in broken cell walls and in promoting the formation of different tissues and organs during plant growth.

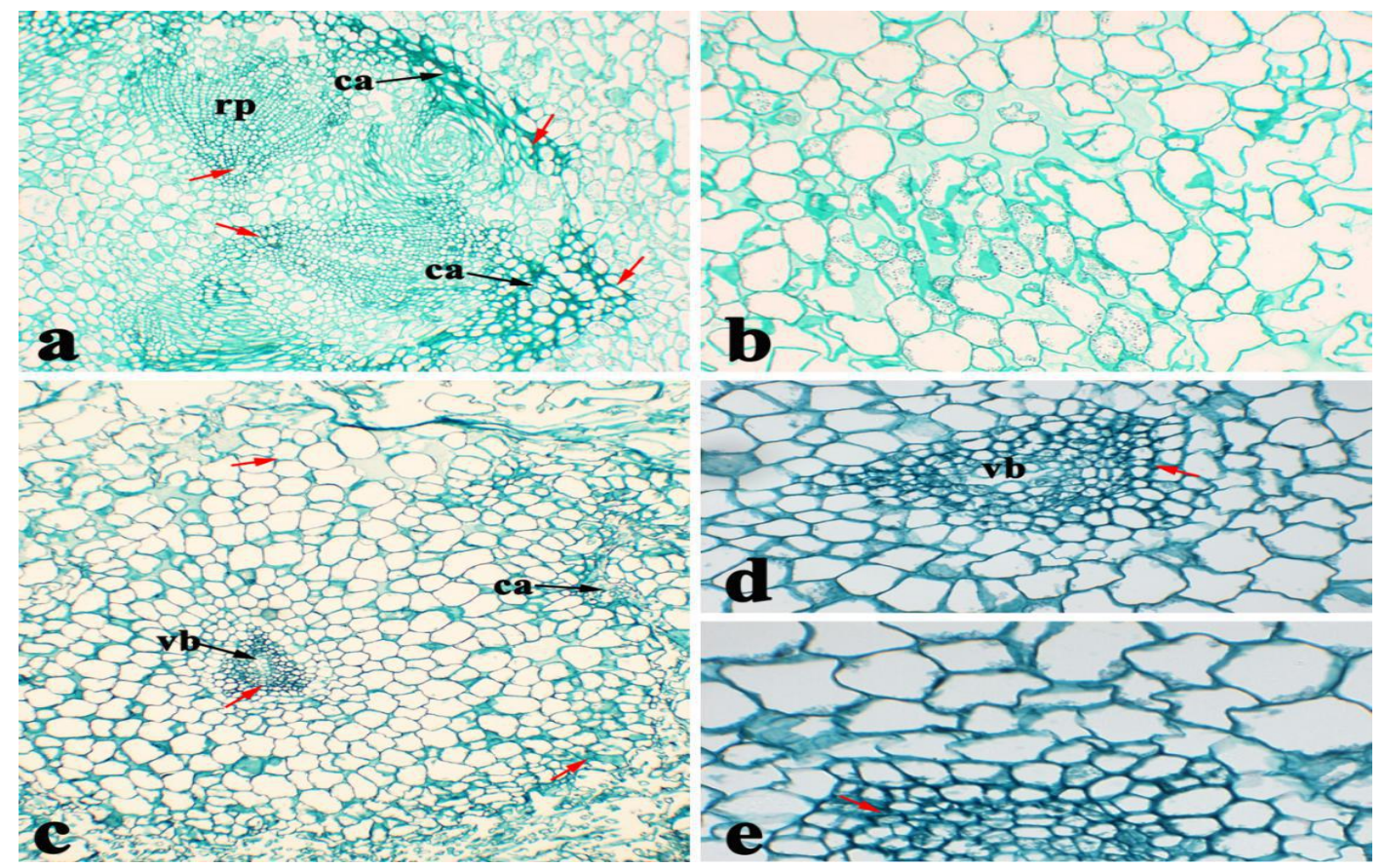

Fig 7 The areas of calli samples having the greatest amount of blue formazan precipitate in Brassica napus cultivar 16NTS309 were sectioned for morphoanatomical analyses. ca, cambium; ep, epidermis; vb, vascular bundle; rp, root primordium. Red arrows were indicated super oxide anion $\left(\mathrm{O}^{2 \cdot-}\right)$ by dispersion polymerization product of blue spots. 
bioRxiv preprint doi: https:/doi.org/10.1101/2020.03 06.980474 this version posted March 6,2020 . The copyright holder for this preprint (which was not certified by peer review) is the author/funder, who has granted bioRxiv a license to display the preprint in perpetuity. It is made available under aCC-BY 4.0 International license.

\subsection{Histochemical staining of onion}

ROS is produced intracellularly, but is it also produced extracellularly? To answer this question,

we conducted our histochemical staining experiments using onions. After exposure to cold stress,

ROS levels increased in onion cells (Fig 8a-e) compared with under normal conditions (Fig 7f).

Plasmolysis generally occurs in cells during cold stress. ROS are not only produced in the
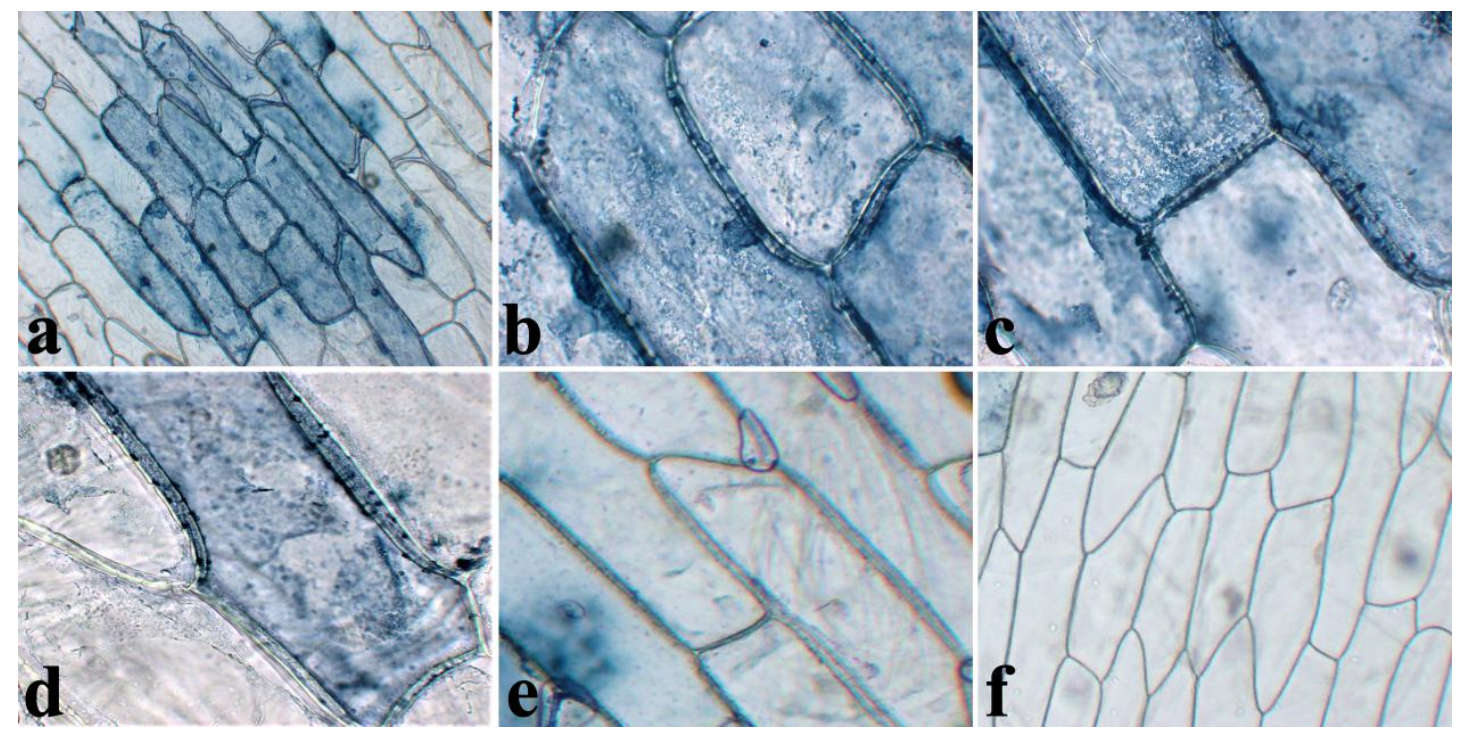

Fig 8 To determine the intracellular and extracellular distribution of $\mathrm{O}^{2--}$, we stained onions with 
With the shift in our understanding of ROS from toxic chemical species to critical signaling molecules, it is important to elucidate the roles of ROS signaling, which could provide new insights into breeding cold-resistant crops.

In higher plants, organ formation occurs continuously and repetitively from shoot and root apical meristems, which are characterized by high cell division rates[24, 29]. More importantly, is the increase in volume of root, leaf and plant cells. This requires the loosening of the cell wall matrix. However, it has been proposed that ROS regulate the cell proliferation cycle[9]and have direct effects on the stiffness of the plant cell wall [30]. During normal metabolic processes, plant cells produce a variety of $\mathrm{ROS}$, including the $\mathrm{O}^{2 .-}, \mathrm{H}_{2} \mathrm{O}_{2}$ and hydroxyl radicals [31]. Here, under normal conditions, $\mathrm{O}^{2--}$ mainly accumulated in leaf edges (Fig 3a, e, f), SAM and LPs (Fig 3c, d), root tips (Fig 3b, 4a), LRPs (Fig 4b), calli of meristematic nodular tissue, cambia, vascular bundles and root primordia (Fig 6a). These cells are characterized by high division rates. This phenomenon confirmed that ROS plays an important role in regulating the balance between cell proliferation and differentiation, as indicated by the histological staining of tissue sections from plant sterile seedlings and calli of B. napus cultivar 16NTS309. The results were verified by assessing the histological staining of onion cells. Our results also confirmed that ROS appeared in

251 the intracellular and extracellular zones, and mainly in the cell wall or membrane, which depends on ROS generation by plasma membrane-localized NADPH oxidases (respiratory burst oxidase homologs), cell wall peroxidases and amine oxidases $[32,33]$. This indicated that $\mathrm{O}^{2--}$ preferentially accumulates in the cell wall or membrane zone. More importantly, the results 
256 wall, because they cleave cell-wall polysaccharides, and they act as wall loosening agents, thereby

257 either stimulating or restricting cellular extension [34, 35], which promotes root and leaf growth 258 and differentiation $[11,12]$.

Abiotic stresses, including osmotic, heavy metal ions and dehydration, are important factors that induce somatic embryogenesis in Arabidopsis [36]. $\mathrm{H}_{2} \mathrm{O}_{2}$ treatments induce somatic embryogenesis, indicating a role for ROS regulation during this process [37]. Recent evidence indicates a potential promotive effect of oxidative stress on the initiation of somatic embryogenesis [38]. After cold stress, ROS levels increased in leaf (Fig 3g, k, l), root (Fig 3h),

(Fig 4f), most calli cells(Fig 7c, d, e) and cambia and vascular bundles (Fig 6b). Because of the ubiquitous role of ROS during abiotic stress signaling and development, these results are not surprising. It was also speculated that a moderate low temperature is an important factor for ROS production, after which ROS play roles in promoting cell division and differentiation. Lastly, new shoots and strong root system formed to increase the adaptability to cold stress. A greater ROS content is not always better for plant health, because excessive ROS accumulations from multiple sources result in "ROS bursts" that damage surrounding cells and severely damage cellular structures [39-42].

\section{Acknowledgement}

274 This study was financially supported by the Agriculture Research System of China (CARS-12);

275 The Agriculture Research System of Gansu Province (GARS-TSZ-1); The Youth Program of 276 Chengdu Normal University ( CS19ZC03 ); 
WL Q and WC S conceived and designed the study. WLQ, W F, L M, P W conducted the experiments. WL Q, WC S analyzed the data.WL Q, JY W, JC W, JJ J contributed reagents, materials, and analysis tools. WLQ wrote the manuscript.We thank Lesley Benyon, $\mathrm{PhD}$, from Liwen Bianji, Edanz Group China (www.liwenbianji.cn/ac), for editing the English text of a draft of this manuscript.

\section{Conflicts of interest statement}

The authors declare no conflict of interest.

\section{References}

1. Rai MK, Kalia RK, Singh R, Gangola MP, Dhawan A. Developing stress tolerant plants through in vitro selection - an overview of the recent progress. Environmental and Experimental Botany. 2011;71(1):89-98.

2. Zhang T, Mao Y, Chen Q, Zhou K, Sun W. Cloning and expression analysis of COR15-like gene in Brassica campestris 'Longyou 6'. Acta Agriculturae Boreali-occidentalis Sinica. 2016;25:707-14.

3. Wu J, Kong D, Fang Y, Sun W, Liu H, Liu Z, Li X. QTL analysis of cold tolerance for Physiological traits in Winter rapeseed(Brassica rpap L.). J. Agric. Res. Arid Areas 35, 2017, 205-210.

4. Mittler R, Vanderauwera S, Gollery M, Van Breusegem F. Reactive oxygen gene network of plants. Trends in plant science. 2004;9(10):490-8.

5. Tripathi DK, Singh S, Singh S, Srivastava PK, Singh VP, Singh S, et al. Nitric oxide alleviates silver nanoparticles (AgNps)-induced phytotoxicity in Pisum sativum seedlings. Plant Physiology and Biochemistry. 2017;110:167-77.

6. Banerjee A, Tripathi DK, Roychoudhury A. Hydrogen sulphide trapeze: environmental stress amelioration and phytohormone crosstalk. Plant Physiology and Biochemistry. 2018;132:46-53.

7. Huang Z, Zhao N, Qin M, Xu A. Mapping of quantitative trait loci related to cold resistance in Brassica napus L. Journal of plant physiology. 2018;231:147-54. 
8. Miller G, Suzuki N, Ciftci - Yilmaz S, Mittler R. Reactive oxygen species homeostasis and signalling during drought and salinity stresses. Plant, cell \& environment. 2010;33(4):453-67.

9. Sarsour EH, Venkataraman S, Kalen AL, Oberley LW, Goswami PC. Manganese superoxide dismutase activity regulates transitions between quiescent and proliferative growth. Aging cell. 2008;7(3):405-17.

10. Owusu-Ansah E, Yavari A, Banerjee U. A protocol for in vivo detection of reactive oxygen species. Protocol Exchange. 2008;10.

11. Dunand C, Crèvecoeur M, Penel C. Distribution of superoxide and hydrogen peroxide in Arabidopsis root and their influence on root development: possible interaction with peroxidases. New Phytologist. 2007;174(2):332-41.

12. Lu D, Wang T, Persson S, Mueller-Roeber B, Schippers JH. Transcriptional control of ROS homeostasis by KUODA1 regulates cell expansion during leaf development. Nature communications. 2014;5:3767.

13. Sun W, Wu J, Zeng J, ZHU H-x, LIU Y-1, ZHANG Y-h. Primary evaluation of cold tolerance among eight winter Brassica rapa. Journal Hunan Agricultural University (Natural Sciences). 2007;33(8):151-5.

14. Sun W. Cultivation techniques of winter oilseed rape in northern arid and cold areas. Chinese Agricultural Press, Beijing; 2013. Tissue Culture: Family Brassicaceae. Biotechnologies of Crop Improvement, Volume 1: Springer; 2018. p. 327-72. responses to cold stress in rapeseed (Brassica napus L.). Journal of Integrative Agriculture. 2019;18(12):2742-52.

17. Pu Y, Liu L, Wu J, Zhao Y, Bai J, Ma L, et al. Transcriptome profile analysis of winter rapeseed (Brassica napus L.) in response to freezing stress, reveal potentially connected events to freezing stress. International journal of molecular sciences. 2019;20(11):2771. 

response and differential signals in chromatin condensation and DNA cleavage in victorin treated oats. The Plant Journal. 2001;28(1):13-26.

20. Wu J, Sun Y, Zhao Y, Zhang J, Luo L, Li M, et al. Deficient plastidic fatty acid synthesis triggers cell death by modulating mitochondrial reactive oxygen species. Cell research. 2015;25(5):621-33.

21. Wardlaw C. On the organization and reactivity of the shoot apex in vascular plants. American Journal of Botany. 1957:176-85.

22. Cutter EG. Recent experimental studies of the shoot apex and shoot morphogenesis. The Botanical Review. 1965;31(1):7-113.

23. Malamy JE, Benfey PN. Organization and cell differentiation in lateral roots of Arabidopsis thaliana. Development. 1997;124(1):33-44.

24. Esau K. Plant anatomy. Plant Anatomy. 1965;(2nd Edition).

25. Charlton W. Lateral root initiation in plant roots. Plant roots \pm the hidden half New York: Marcel Dekker. 1991:107-28.

26. Sugimoto K, Jiao Y, Meyerowitz EM. Arabidopsis regeneration from multiple tissues occurs via a root development pathway. Developmental cell. 2010;18(3):463-71.

27. Sugimoto K, Gordon SP, Meyerowitz EM. Regeneration in plants and animals:

352 dedifferentiation, transdifferentiation, or just differentiation? Trends in cell biology. 2011;21(4):212-8.

28. Perianez-Rodriguez J, Manzano C, Moreno-Risueno MA. Post-embryonic organogenesis and plant regeneration from tissues: two sides of the same coin? Frontiers in plant science. 2014;5:219. 29. McCully M. The development of lateral roots in The Development and Function of Roots. Academic Press: New York; 1975.

30. Gonzalez N, Vanhaeren H, Inzé D. Leaf size control: complex coordination of cell division

359 and expansion. Trends in plant science. 2012;17(6):332-40.

360 31. O’Brien JA, Daudi A, Butt VS, Bolwell GP. Reactive oxygen species and their role in plant 361 defence and cell wall metabolism. Planta. 2012;236(3):765-79.

362 32. Kadota Y, Shirasu K, Zipfel C. Regulation of the NADPH oxidase RBOHD during plant 363 immunity. Plant and Cell Physiology. 2015;56(8):1472-80. 

by NADPH oxidase are involved in pollen tube growth. New Phytologist. 2007;174(4):742-51. generation of hydroxyl radicals mediating extension growth. Planta. 2003;217(4):658-67. 35. RODRIGO - MORENO A, ANDRÉS - COLÁS N, Poschenrieder C, Gunse B, Penarrubia L, Shabala S. Calcium - and potassium - permeable plasma membrane transporters are activated by copper in Arabidopsis root tips: linking copper transport with cytosolic hydroxyl radical production. Plant, Cell \& Environment. 2013;36(4):844-55.

36. Ikeda - Iwai M, Umehara M, Satoh S, Kamada H. Stress - induced somatic embryogenesis in vegetative tissues of Arabidopsis thaliana. The Plant Journal. 2003;34(1):107-14.

37. Zavattieri MA, Frederico AM, Lima M, Sabino R, Arnholdt-Schmitt B. Induction of somatic embryogenesis as an example of stress-related plant reactions. Electronic Journal of Biotechnology. 2010;13(1):12-3.

38. Becker MG, Chan A, Mao X, Girard IJ, Lee S, Elhiti M, et al. Vitamin C deficiency improves somatic embryo development through distinct gene regulatory networks in Arabidopsis. Journal of experimental botany. 2014;65(20):5903-18 .

39. Ali S, Gill R, Mwamba T, Zhang N, Lv M, ul Hassan Z, et al. Differential cobalt-induced effects on plant growth, ultrastructural modifications, and antioxidative response among four Brassica napus (L.) cultivars. International Journal of Environmental Science and Technology. 2018;15(12):2685-700.

40. Chen S, Dickman MB. Bcl-2 family members localize to tobacco chloroplasts and inhibit programmed cell death induced by chloroplast-targeted herbicides. Journal of Experimental Botany. 2004;55(408):2617-23. virulence and survival of Fusarium graminearum. Molecular plant-microbe interactions. 2012;25(12):1617-27. short-term salt stress: focus on chlorophyll degradation, photosynthesis, hormone and leaf 